\title{
ESPETACULARIZAÇÃO DA VIOLÊNCIA E A RESISTÊNCIA NA CONTÍSTICA DE CLARICE LISPECTOR E CAIO FERNANDO ABREU
}

\author{
SPECTACULARIZATION OF VIOLENCE AND RESISTANCE IN THE CONTISTIC OF CLARICE \\ LISPECTOR AND CAIO FERNANDO ABREU
}

\section{Rennan Willian Vasconcelos FERREIRA (UFPA Augusto SARMENTO-PANTOJA (UFPA) ${ }^{2}$}

\begin{abstract}
RESUMO: Este artigo analisa a espetacularização da violência e resistência encontrados na contística brasileira produzida pós-64, em dois contos $A$ língua do " $P$ ", (1974) de Clarice Lispector, e Terça-feira gorda (1982), de Caio Fernando Abreu,. Essas produções, se aproximam por servirem como um importante mecanismo de contestação, de forma direta e/ou indireta, ao regime ditatorial instaurado no país. Tomaremos como fundamentação teórica os estudos de Alfredo Bosi (2002), Augusto Sarmento-Pantoja (2013) e Sandra Pesavento (2006), na tentativa de assimilar como os contos de tais décadas estão atrelados intrinsicamente a uma vontade de resistir, concebendo as vozes aos silenciados pela opressão e proporcionando reflexões a respeito das práticas coercivas que levaram o indivíduo a repensar sua condição humana.
\end{abstract}

Palavras-chave: Espetacularização da. Resistência. Conto. Clarice Lispector. Caio Fernando Abreu.

\begin{abstract}
This article analyzes the spectacularization of violence and resistance found in Brazilian short stories produced after 1964, in two short stories A lingua do "P", (1974) by Clarice Lispector, and Terça-feira Gorda (1982), by Caio Fernando Abreu. These productions come closer as they serve as an important mechanism for contesting, directly and/or indirectly, the dictatorial regime established in the country. We will take as theoretical foundation the studies of Alfredo Bosi (2002), Augusto Sarmento-Pantoja (2013) and Sandra Pesavento (2006), in an attempt to assimilate how the tales of such decades are intrinsically linked to a will to resist, conceiving the voices to the silenced by oppression and providing reflections on the coercive practices that led the individual to rethink their human condition.
\end{abstract}

Key words: Spectacularization of violence. Resistance. Tale. Clarice Lispector. Caio Fernando Abreu.

\footnotetext{
${ }^{1}$ Graduado em Licenciatura em Letras, Campus Universitário de Abaetetuba. Foi bolsista de Iniciação Científica PIBIC/CNPQ. E-mail: rennan-willian@hotmail.com

${ }^{2}$ Doutor em Teoria e História Literária pela UNICAMP. Professor de Literatura da Universidade Federal do Pará (UFPA), coordenador do grupo de pesquisa Estéticas, Performances e Hibridismos (ESPERHI), pesquisador do grupo Estudos de Narrativas de Resistência (NARRARES)E-mail: augustos@ufpa.br
} 


\section{INTRODUÇÃO}

Caio Fernando Abreu sempre se declarou um fã incondicional de Clarice Lispector, assumindo, inclusive, em diversos momentos, a importância e influência da autora dentro de sua própria produção literária. Essa relação é exposta em uma carta escrita para o jornalista e amigo José Márcio Penido, em 1979, publicada como anexo do livro Morangos Mofados ${ }^{3}$. Na carta, Caio Fernando Abreu relata como conheceu Clarice Lispector e descreve suas impressões:

Eu conheci razoavelmente bem Clarice Lispector. Ela era infelicíssima, Zézim. A primeira vez que conversamos eu chorei depois a noite inteira, porque ela inteirinha me doía, porque parecia se doer também, de tanta compreensão sangrada de tudo. Te falo nela porque Clarice, pra mim, é o que mais conheço de GRANDIOSO, literariamente falando. E morreu sozinha, sacaneada, desamada, incompreendida, com fama de meia "doida". Porque se entregou completamente ao seu trabalho de criar. Mergulhou na sua própria trip e foi inventando caminhos, na maior solidão. Como Joyce. Como Kafka, louco e só lá em Praga. Como Van Gogh. Como Artaud. Ou Rimbaud. (ABREU, 2005, p. 154) (grifos do autor)

Contemporâneos, ainda que por um breve período, Caio e Clarice foram dois grandes representantes da literatura urbana produzida no Brasil durante o século XX. Nessa literatura, os temas e personagens estão envoltos pela realidade dos grandes espaços citadinos, como é o caso da violência, enfoque desta pesquisa. Caio, assim como Clarice, nas devidas proporções, traz à tona a perspectiva do cotidiano, de forma universal e ao mesmo tempo a partir de uma ótica psicológica e altamente intimista. Conforme destaca Amanda Lacerda Costa (2008),

Com a evolução tecnológica e industrial, a sociedade citadina assume um caráter capitalista, levando seus habitantes ao desequilíbrio e ao isolamento, voltando-se para e sobre si mesmos. A literatura urbana, pela vertente intimista, reflete esse processo, apresentando uma ótica centrada na interioridade das personagens e na psicologia individual, cujo principal procedimento narrativo é a prosa de introspecção. (COSTA, 2008, p. 10)

Sendo assim, em ambos os escritores, percebe-se uma preocupação com indivíduo e o seu estar num mundo construído à base de máscaras que, em um determinado momento, acabam por ser arrancadas. Percebe, pois, uma aproximação da obra de Clarice Lispector e Caio Fernando Abreu no que concerne ao desnudamento do sujeito perante o mundo.

Nesta pesquisa, detemos os olhares sobre a contística desses autores, no intuito de investigar a violência apresentada no texto literário produzido nas décadas de 1970 e 1980. Outro aspecto desta

${ }^{3}$ Esta carta se encontra publicada na $1^{\text {a }}$ reimpressão do livro pela editora Agir, no ano de 2005. 
investigação se refere às formas de espetacularização ${ }^{4}$ do trauma, da dor e do sofrimento de personagens, ao mesmo tempo comuns e incomuns, descrita por esses escritores. Essas narrativas, ao discutirem a violência e a espetacularização, se tornam um importante instrumento de resistência e questionamento do regime ditatorial (1964-1985) brasileiro.

A ditadura civil-militar, expressão cunhada pelo historiador Daniel Aarão Reis ${ }^{5}$, e que usaremos no decorrer desta discussão, instaurou um cenário de instabilidade, repressão, torturas e perseguições a todos aqueles que, de alguma forma, eram vistos como uma ameaça aos olhos do regime, principalmente por se manifestarem a favor dos direitos democráticos e da liberdade de expressão.

Sentindo, então, a necessidade de dar voz ao sofrimento de outros e de si, inúmeros artistas buscaram mecanismos para driblar a censura e, dessa forma, resistir ao autoritarismo. Clarice Lispector e Caio Fernando Abreu fazem parte dessa leva de artistas que usaram a literatura para dar voz aos silenciados pela opressão. Não obstante, vale ressaltar que tanto Clarice Lispector quanto Caio Fernando Abreu não são considerados necessariamente autores engajados à resistência política. Porém, ao nascerem no contexto da ditadura civil-militar e ao tematizarem problemáticas sociais, a exemplo da violência, suas obras estão propícias a tais interpretações.

Nesta pesquisa, tomaremos como objeto de análise, especificamente, dois contos, que apesar de terem sido produzidos em décadas diferentes, estabelecem pontos de contato fundamentais para entendermos a relação violência-resistência durante a ditadura civil-militar brasileira. São eles: $A$ língua do "P" (1974), que pertence ao livro A Via Crucis do Corpo, de Clarice Lispector; e Terçafeira gorda, que integra a obra Morangos Mofados (1982), de Caio Fernando Abreu.

A Via Crucis do Corpo, obra de Clarice Lispector, publicada a partir de um desafio lançado por Álvaro Pacheco, seu então editor na Artenova. Ele encomendara três contos baseados em fatos reais, o que, num primeiro momento, Clarice hesitou em aceitar. A autora, entretanto, não só atendeu ao pedido como também foi muito além do esperado: entre os dias 11 a 13 de maio de 1974, escreveu as 13 narrativas que compõem a coletânea. Benjamin Moser ressalta que

\footnotetext{
${ }^{4} \mathrm{O}$ conceito de espetacularização está quase sempre atrelado a um caráter pejorativo, a exemplo de inúmeras mídias sensacionalistas, preocupadas exclusivamente com o consumo e mero entretenimento por meio da banalização de imagens. Entendemos, porém, que a espetacularização deve, muito mais do que entreter, proporcionar a reflexão. É necessário, portanto, evidenciar, expor de forma exacerbada a problemática em questão, para que assim ocorra o processo de catarse.

${ }^{5} \mathrm{O}$ texto $A$ ditadura civil-militar, de Daniel Aarão Reis, no qual o historiador defende o uso da expressão que usaremos nesta pesquisa, encontra-se publicado no jornal $O$ Globo. Acesso em https://blogs.oglobo.globo.com/prosa/post/aditadura-civil-militar-438355.html .
} 
O livro é desafiadora e desbragadamente sexual, de um modo que Clarice nunca fora antes e nunca voltaria a ser. Em suas oitenta e poucas páginas encontramos um travesti, uma stripper, uma freira tarada, uma mulher de sessenta anos com um amante adolescente, um casal de lésbicas assassinas, uma velha que se masturba e uma secretária inglesa que tem um coito extático com um ser do planeta Saturno. (MOSER, 2013, p. 335)

O livro, quando na época de sua publicação, recebeu inúmeras críticas negativas, o que, a princípio, é muito compreensível. Trata-se de uma obra que muito se difere do que Clarice havia produzido até então, especialmente nas temáticas abordadas pelas narrativas. A autora, cujos textos constituíam um retrato do cotidiano da classe média, agora refletia a realidade dos marginalizados. Entendendo, portanto, a natureza revolucionária da obra, não só para a produção de Clarice Lispector, mas também para a literatura brasileira, selecionados o conto A língua do " $P$ " como objeto de análise deste trabalho.

Morangos Mofados, de Caio Fernando Abreu, é uma das obras mais conhecidas do escritor gaúcho. Heloisa Buarque de Holanda ${ }^{6}$ reflete que

o que primeiro chama a atenção nesse livro é um certo cuidado, uma enorme delicadeza em lidar com a matéria da experiência existencial de que fala. [...] Apesar da tentativa de olhar com certo distanciamento histórico-existencial [...], Morangos não deixa de revelar uma enorme perplexidade diante da falência de um sonho e da certeza de que é fundamental encontrar uma saída capaz de absorver, agora sem a antiga fé, a riqueza de toda essa experiência. (HOLANDA, 2018, p. 754)

Composto por 18 contos, o livro revela, de forma intimista, os anseios, medos, angústias e frustrações vividas durante a ditadura civil-militar brasileira, especialmente por grupos subalternizados pelo regime, como é o caso dos homossexuais. Da obra, escolhemos como objeto de análise para este texto o conto Terça-feira gorda.

A escolha de tais contos se dá, principalmente, porque em ambas as narrativas é possível identificar os traços da violência associados ao espaço urbano ${ }^{7}$. Tanto no conto de Clarice Lispector quanto no de Caio Fernando Abreu é possível identificar a assiduidade de personagens imersos em grandes cidades, que se veem obrigados a cumprir um papel social pré-determinado. É justamente nesse ambiente citadino, o qual oprime e sufoca o indivíduo com suas tarefas e cotidiano, que a

\footnotetext{
${ }^{6} \mathrm{O}$ texto Hoje não é dia de rock, de Heloisa Buarque de Holanda, publicada inicialmente no Jornal do Brasil em 1982 , serve de posfácio para a coletânea Contos Completos, de Caio Fernando Abreu, publicada pela Companhia das Letras, no ano de 2018.

${ }^{7}$ Sabemos que a violência não se restringe ao século XX, mas por conta de diversas transformações sociais e políticas, este tema ganha maior destaque no século XX, no início do século, com expressões literárias ligadas aos espaços rurais ou regionais, aos poucos passando a problematização dessa violência nos espaços urbanos.
} 
violência aparecerá, seja de uma forma interna e/ou externa ao indivíduo. Como ressalta Ana Paula Brandileone, ao analisar a exclusão e opressão social do sujeito frente aos grandes espaços citadinos,

a experiência urbana está comumente associada a sujeitos sociais cindidos, fragmentados, desenraizados, abandonados à deriva, porque expostos à violência de uma sociedade urbana burocrática, impessoal, que exclui, tem preconceitos e que age desprovida de qualquer entendimento lógico ou controle humano. (BRANDILEONE, 2014, p. 217)

Sendo assim, consideramos relevante a comparação entre os contos de Clarice Lispector e Caio Fernando Abreu pelo fato de que, nos anos de 1970 e 1980, encontramos similaridades e diferenças marcantes das formas da violência no texto literário, como destaca Italo Moriconi (2009) na apresentação da antologia Os Cem Melhores Contos Brasileiros do Século. Segundo ele, o conto, na década de 1970, "quer trazer à tona o outro lado - o lado violento e obscuro da realidade" (MORICONI, 2009, p. 281). A década de 1980, por sua vez, fornece ao conto histórias de violência relacionadas à erotização do corpo e o despertar sexual. Por isso, faz-se necessário analisar quais os questionamentos levantados pelos autores em suas produções e como a espetacularização da violência está imersa no texto literário, atribuindo a essas obras um caráter de resistência política, social e/ou ideológica frente à ditadura civil-militar.

\section{A ESPETACULARIZAÇÃO DA VIOLÊNCIA NA FICÇÃO BRASILEIRA CONTEMPORÂNEA}

Constituo o início desta seção com uma passagem de Tânia Pelegrini (2008, p. 41):

Há quem afirme que o conjunto da literatura brasileira atualmente exige novos modelos de análise, capazes de estimular novas leituras e interpretações, uma vez que a tendência à exacerbação da violência e da crueldade, com a descrição minuciosa de atrocidades, sevícias e escatologia, vem pontuando cada vez mais tanto narrativas literárias quanto audiovisuais, do cinema ou da televisão. Como se a dramatização do princípio da violência passasse a ser diretriz principal da organização formal, com seu caráter inarredável e obsceno, subsumindo tempos e espaços, personagens e situações.

As reflexões de Pellegrini nos levam a dois pontos de discussão distintos e igualmente entrelaçados. Em primeira instância, é necessário evidenciar o fato de que a literatura brasileira contemporânea está marcada pelas chamadas "narrativas de violência", isto é, uma prosa na qual a violência simbólica e/ou social compõe a tessitura do texto. Alfredo Bosi (2006) também chamou atenção para esse aspecto, ressaltando o "estilo de narrar brutal, se não intencionalmente brutalista" 
(2006, p. 434-435), dos escritores contemporâneos ao notabilizam cenas de crueldade, tanto físicas quanto psicológicas, contra o indivíduo. O segundo aspecto a ser realçado, pela citação de Pellegrini, é a exacerbação da violência nas produções literárias das últimas décadas do século XX. Essa intensa exposição da violência atrelada ao sujeito está relacionada ao conceito de espetacularização, do qual nos apropriaremos para fundamentar esta pesquisa.

Antes de mais nada, é importante esclarecermos que usaremos as proposições de Augusto Sarmento-Pantoja (2013) a respeito do conceito de espetacularização, uma vez se trata de um dos poucos autores que analisam essa categoria sob uma ótica de importância ética e social. Isso porque a noção de espetacularização não está aqui associada a um simples processo de banalização das imagens, como comumente encontramos em mídias sensacionalistas, as quais expõem cenas de violência, por exemplo, com um único propósito de consumo. Sendo assim, valemo-nos da convicção de que quanto mais evidente as imagens estiverem aos espectadores, melhor será para se desvelar o que está encoberto por essas imagens.

Patrice Pavis define o espetáculo como sendo "tudo o que se oferece ao olhar" (1999, p. 141). A partir dessa definição, é possível inferir que o espetáculo está diretamente ligado à concepção de imagens, valendo o performer das diversas manifestações artísticas para representar uma realidade. Todavia, muito mais do que um simples entretenimento através de imagens, o espetáculo denuncia um mundo encoberto: a realidade representada, por vezes, nada mais é do que uma camuflagem, uma forma alternativa de esconder e ao mesmo tempo expor paralelamente uma realidade. É o caso dos contos selecionados para análise nesta pesquisa, os quais foram produzidos à época da ditadura civilmilitar no Brasil. Tendo em vista a forte censura a todos aqueles que se manifestassem contra o regime, os escritores exploraram estratégias literárias para velar as críticas contra o autoritarismo. Esse caráter dúbio quanto ao espetáculo nem sempre é percebido pelos espectadores, que acabam por não desvelar o que está por “detrás das cortinas”. Faz-se necessário, portanto, expor, espetacularizar, colocar em evidência, para que a problemática seja discutida e repensada. Ressaltamos, porém, que a espetacularização, ainda que se caracterize pela exacerbação de imagens, também encobre uma realidade. A exemplo disso, Sarmento-Pantoja elabora um anagrama de correlações entre as imagens que, segundo ele, se relacionariam em quatro pontos fundamentais: "a imagem que vemos; a imagem que queremos ver; a imagem que não queremos ver; e a imagem daquilo que não vemos" (2013, p. 96).

O trabalho em questão, como já mencionado anteriormente, se propõe em analisar e discutir as categorias violência e resistência em manifestações literárias no Brasil, mais especificamente na 
contística dos anos 1970 e 1980. Nessas narrativas, é evidente a espetacularização de imagens de violência, geralmente ligadas a espaços citadinos. Portanto, questionamo-nos quanto à função dessa espetacularização por parte dos escritores contemporâneos. Para nós, é de grande valor entendermos o que está por trás da exposição de cenas literárias nas quais os personagens têm seus corpos violados por forças externas, que causam dor, fragilizam e traumatizam suas vítimas. Como destaca SarmentoPantoja, "mesmo quando não se pensa nas intenções diretas acerca de uma obra, temos nela um conjunto de discursos ali construídos que refletem uma prática social, histórica, humana, representativa do conflito entre imagem e realidade" (SARMENTO-PANTOJA, 2013, p. 99).

Buscamos evidenciar outras possibilidades da espetacularização da violência nos contos que compõem o corpus literário desta pesquisa, entendendo que o próprio ato de espetacularizar concatena uma série de discursos, especialmente no que concerne à resistência política, ideológica e/ou social. Como destaca Alfredo Bosi, a resistência está ligada à "força da vontade que resistência a outra força, exterior ao sujeito" (2002, p. 11). Sendo assim, levantamos dois questionamentos: de que forma a exacerbação de cenas de violência está associada ao ato de resistir? E por que o gênero conto, ao espetacularizar a violência, foi uma das principais ferramentas de resistência no Brasil dos anos de 1970 e 1980 ?

É evidente que, a partir dos anos de 1970 o conto passa a ser o gênero de maior efervescência no cenário literário brasileiro, como destaca Regina Dalcastagnè, no que concerne à produção contística no Brasil,

nunca se publicou tanto. Nunca tantos escritores foram apresentados ao público. Concursos, jornais, revistas especializadas e antologias divulgavam novos autores, criavam renomes passageiros e mesmo consagravam definitivamente alguns, que passariam a fazer parte da vida literária do País. (DALCASTAGNÈ, 2001, p. 4)

É muito curioso que a efervescência literária do gênero conto tenha ocorrido, no Brasil, durante os anos de 1970, visto que nesse período o país vivia os piores momentos da ditadura civilmilitar, nos quais havia uma forte censura e repressão, principalmente dentro dos meios midiáticos, como os jornais, onde o conto mais se fortaleceu. Karl Erik Schøllhammer ressalta, entretanto, que os anos de 1970 se impuseram sobre os escritores "com a demanda de encontrar uma expressão estética que pudesse responder à situação política e social do regime autoritário" (2009, p. 22). Dessa forma, os autores que se valeram do gênero conto, ao refletirem em suas narrativas a realidade social dos grandes conglomerados urbanos, também refletiram os momentos de tensão advindos da ditadura civil-militar, tendo a violência como tema recorrente nessas produções. Sendo assim, a 
espetacularização da violência se fez necessária para denunciar e chamar a atenção aos problemas sociais do seu tempo.

Sandra Pesavento (2006), em seu artigo Memória e história: as marcas da violência, evidencia a violência na história da humanidade, sendo pertinente, portanto, na literatura. Pesavento chama a atenção para a presença da violência em diversas narrativas mitológicas, a exemplo de alguns textos bíblicos, como a batalha dos arcanjos São Miguel e Lúcifer; ou o primeiro assassinato, cometido por Caim para com o seu irmão Abel. Segundo a autora, esses mitos nada mais eram do que tentativas do homem de explicar a sua própria existência. Dessa forma, os problemas sociais que acometem o homem eram postos em destaque, no intuito de compreendê-los com maior precisão, para que assim se pudesse propor soluções e traçar novos rumos, como é caso da violência. Ao discutir sobre as diversas formas de representatividade da violência ao longo da história da humanidade:

os homens não deixaram de construir, ao longo dos séculos, imagens e discursos sobre o fenômeno da violência, forma de enfrentamento que se revela associada a outros tantos conceitos e práticas, como a destruição, a morte, o aniquilamento da identidade, individual e coletiva, a intolerância, a dificuldade de conviver com a diferença, a construção da exclusão social e a prática de atos cruéis contra populações indefesas. (PESAVENTO, 2006, p. 2)

Tal como nas histórias mitológicas, a violência recebeu um olhar atento na contística dos escritores contemporâneos brasileiros da segunda metade do século XX. Como já destacado anteriormente, ao espetacularizar a violência, a contística dos escritores brasileiros se mostrou um mecanismo eficaz de resistência ao regime ditatorial, uma vez que a literatura pós-64 se compromete em criticar a realidade social e política e, dessa forma, a própria ditadura civil-militar. $\mathrm{O}$ escritor pós64 tem, pois, o compromisso de combater as formas de autoritarismo e de lutar, como nas próprias palavras de Pesavento, contra o "aniquilamento da identidade individual e coletiva" (Ibidem).

Sendo assim, é imprescindível espetacularizar a violência, colocar o leitor-indivíduo diante de uma situação-limite, para que ele possa confrontar-se com o que, talvez, até então estivesse camuflado, escondido “debaixo do tapete”. Faz-se necessário mostrar a ele as consequências da intolerância contra o outro, advinda de um estado que renega os direitos democráticos, voltando-se para os seus próprios interesses e, assim, excluindo o "diferente".

Salientamos aqui as ideias de Giorgio Agamben, no que concerne ao papel do escritor contemporâneo. Suas reflexões nos inferem que o

contemporâneo é aquele que mantém fixo o olhar no seu tempo, para nele perceber não as luzes, mas o escuro. [...] Contemporâneo é, justamente, aquele que sabe ver 
essa obscuridade, que é capaz de escrever mergulhando a pena nas trevas do presente. (AGAMBEN, 2009, p. 63)

Dessa forma, o escritor brasileiro contemporâneo, por meio do gênero conto, se deteve em fixar o olhar, entre as décadas de 1970 e 1980, na obscuridade advinda do regime ditatorial, que deixou profundas cicatrizes na história do país e que, ainda hoje, reverberam. A espetacularização da violência, nesse sentido, promove o questionamento, denuncia o autoritarismo e ressignifica o status quo, uma vez que os escritores dão voz aos silenciados pela opressão, colocando em destaque as minorias, por meio da ficcionalização de suas narrativas e, assim, fazendo jus, como ressalta Augusto Sarmento-Pantoja (2014, p. 11), à natureza revolucionária da arte, que é a imersão nos signos de resistência.

Os contos que serão analisados nas próximas seções problematizam questões relacionadas a dois grupos subalternizados pela ditadura-civil militar: mulheres e homossexuais. A partir dos anos de 1960, influenciadas pelos movimentos feministas que aconteciam em diversas partes do mundo, as mulheres conquistaram mais espaço em vários setores sociais, a exemplo do ingresso nas universidades, buscando discutir a atingir a autonomia sobre o próprio corpo. Essas mudanças não foram vistas com bons olhos pelo regime ditatorial, uma vez que, para os mais conservadores, as mulheres deveriam estar restritas aos afazeres dos ambientes domésticos, bem como, a um comportamento recatado. Os homossexuais, considerados subversivos, também tiveram seus direitos cerceados durante a ditadura civil-militar, especialmente a partir do ano de 1968, com a execução do AI-5, o qual coibiu quaisquer formas de reinvindicação contra o regime.

Diante disso, buscamos entender como a contística de Clarice Lispector e Caio Fernando Abreu, nascida em plena ditadura civil-militar, colocou em debate, por meio da espetacularização da violência, a realidade de tais grupos, configurando-se como um importante ato de resistência política, ideológica e/ou social, ainda que os autores em questão, como já realçado anteriormente, não sejam conhecidos por seu engajamento frente à resistência política.

\section{CLARICE E SUA LÍNGUA DO “P”}

Clarice Lispector é uma das vozes femininas mais expressivas da literatura brasileira do século XX, ao lado de Lygia Fagundes Telles, Rachel de Queiroz e Hilda Hilst. Em seus anos de atuação como escritora, produziu romances, crônicas, cartas e inúmeros contos. Nesta seção, analisaremos $A$ língua do " $P$ ", um dos contos que compõem a coletânea $A$ Via Crucis do Corpo. A escolha do texto em questão se justifica pela exposição de cenas de violência contra a mulher na tessitura da narrativa. 
Sendo assim, pretendemos analisar quais os questionamentos levantados pela autora ao espetacularizar essas cenas de violência e como essa espetacularização se enquadra nos signos de resistência.

Antes de mais nada, é necessário frisar que a temática da violência contra a mulher não é nenhuma novidade na literatura brasileira. Machado de Assis, no início do século XX, já falava sobre o mesmo tema em Pai contra a mãe. No conto Negrinha, de Monteiro Lobato, é outro exemplo dessa espetacularização da violência em contos brasileiros. Os maus tratos vão desde apelidos maldosos até castigos severos, como é o caso da angustiante cena do ovo quente, em Negrinha, ou em como Pai contra mãe, que a violência está assinada pelo direito.

A partir da segunda metade do século XX, mais especificamente a década de 1970, com a propagação dos ideais feministas em território brasileiro, o universo feminino passa a ser tematizado com maior precisão na literatura. Tem-se, nesse momento, um número considerável de escritoras atuando no país, a exemplo de Clarice Lispector, cuja obra será objeto de análise nesta seção. Nesse ínterim, ao representarem o universo feminino em suas produções, as autoras também colocaram em evidência, obviamente, os desafios ligadas a esse grupo, a título dos aspectos relacionados à violência física e/ou simbólica. É importante ressaltarmos aqui o conceito de lugar de fala, uma vez que ele será imprescindível para a compreensão da obra de Clarice Lispector e, mais adiante, de Caio Fernando Abreu. Nas palavras de Arthur Oriel Pereira,

Lugar/posição de fala não se refere necessariamente a indivíduos dizendo algo; é um conceito que parte da perspectiva de que as visões de mundo se apresentam desigualmente posicionadas. [...] Trata-se de uma análise a partir da localização dos grupos nas relações de poder, levando em conta os marcadores sociais de raça, gênero, classe, geração e sexualidade como elementos dentro de construções múltiplas na estrutura social. Portanto, o conceito parte das múltiplas condições que resultam as desigualdades e hierarquias que localizam grupos subalternizados. (PEREIRA, 2018, p. 155)

As reflexões de Pereira nos possibilitam inferir que a principal diferença entre as obras do início do século XX para com aquelas produzidas em sua segunda metade consiste justamente no lugar de fala, visto que agora grupos subalternizados usam suas próprias vozes para denunciar situações-limite. Dessa forma, segundo Carlos Magno Gomes, as escritoras passam a questionar, a partir dos anos 70, "as diferentes formas de violência contra a mulher que vão do assédio moral, passando pelo espancamento, até chegar ao feminicídio" (GOMES, 2013, p. 3). Há, portanto, uma autêntica propriedade ao refletir o universo feminino no texto literário. 
Ao entendermos que Clarice Lispector é uma das principais representantes da chamada "literatura feminina" brasileira, uma vez que usou de seus escritos para questionar o papel da mulher em uma sociedade marcada pela repressão e silenciamento, propomo-nos aqui em discorrer sobre a espetacularização da violência em um conto da escritora ucraniana radicalizada no Brasil.

A Via Crucis do Corpo, por tratar-se de uma obra por encomenda, a escritora valeu-se de uma certa liberdade dentro de sua produção para tratar de temas até então nunca explorados em seus livros, como é o caso, por exemplo, da homossexualidade, tão evidente em contos como Ele me bebeu e Praça Mauá. É importante destacarmos aqui o que consideramos como o primeiro ato de resistência em relação à obra. Sarmento-Pantoja, ao discutir a complexidade do conceito de resistência e ao pontuar a importância de Alfredo Bosi para a compreensão desse conceito, ressalta que "o sentido de resistir passa pela oposição, mesmo que ela seja a si mesmo" (SARMENTO-PANTOJA, 2014). Sendo assim, podemos inferir que Clarice Lispector, ao escrever A Via Crucis do Corpo, faz resistência à sua própria produção literária, como ela evidencia a seguir: "sei lá se este livro vai acrescentar alguma coisa à minha obra. Minha obra que se dane. Não sei por que as pessoas dão tanta importância à literatura. E quanto ao meu nome? que se dane, tenho mais em que pensar" (LISPECTOR, 2016, p. 564).

Entendemos, todavia, que o ato de resistir em Clarice Lispector vai além da oposição à própria obra. Dessa forma, buscamos analisar os signos de resistência a partir da espetacularização de cenas de violência contra a mulher no conto $A$ língua do " $P$ ". Também já mencionamos anteriormente que a espetacularização, muito mais do que uma mera banalização de imagens, como negativamente costuma-se a associa-la, está ligada à evidenciação de uma problemática, para que assim ocorra um processo de reflexão e discussão em torno do problema em questão. Faz-se necessário, pois, uma análise das cenas de violência contra a mulher espetacularizadas no conto, a fim de uma melhor percepção a respeito dos aspectos de resistência na obra da autora.

Em A língua do " $P$ ”, assim como em grande parte das narrativas de Clarice Lispector, temos a figura feminina em evidência, representada no conto pela protagonista Cidinha. A autora esboça ao leitor, já no primeiro momento da narrativa, o perfil da jovem. Trata-se de uma moça remediada, inteligente, educada, virgem e professora de inglês, que anseia em viajar para os Estados Unidos no intuito de aperfeiçoar-se. A descrição oferecida por Clarice Lispector faz-se mais do que necessária e intencional, uma vez que a personagem, assim como as protagonistas de outras obras da autora, sofrerá uma transformação à medida em que o conto se desenrolar. Gomes reflete que, nos anos de 1970, a ficção brasileira, especialmente aquela produzida por mulheres, evidenciou "a luta feminista 
pela liberdade do corpo da mulher, pelo controle de maternidade e por sua independência financeira" (GOMES, 2013, p. 04). Sendo assim, o perfil de Cidinha, projetado pela autora, parece sugerir, ainda que superficial e parcialmente, um empoderamento feminino, ao mesmo tempo em que sugere também uma espécie de retraimento da mulher.

O conto escrito em terceira pessoa, por meio de uma linguagem simples e objetiva, confere à narrativa um caráter jornalístico-ficcional. A trama gira em torno de Cidinha que, ao tomar o trem de Minas Gerais com destino ao Rio de Janeiro, vê-se em uma situação desesperadora. Isso porque a moça se torna alvo de dois homens, os quais planejam estupra-la e assassina-la. No intuito de impedir que as pessoas ao redor descubram seus planos, os homens se comunicam por meio da língua do "p", a qual intitula o conto. Cidinha, porém, compreende a língua secreta usada pelos homens e entra em estado de agonia profunda. Decide, portanto, vulgarizar-se, para que assim os homens desistam de agredi-la.

Então pensou: se eu me fingir de prostituta, eles desistem, não gostam de vagabunda. Então levantou a saia, fez trejeitos sensuais - nem sabia que sabia fazê-los, tão desconhecida ela era de si mesma - abriu os botões do decote, deixou os seios meio à mostra. Os homens de súbito espantados. (LISPECTOR, 2016, p. 580)

Com a decisão de Cidinha, Clarice Lispector chama a atenção do leitor para um questionamento de extrema importância: a liberdade feminina. Gomes (2013) reflete sobre a metáfora da liberdade feminina como parte do projeto estético dessa literatura. É o que encontramos, por exemplo, em A língua do " $P$ ”. Mais do que uma forma de escapar dos agressores, a vulgarização de Cidinha no conto denuncia a repressão sexual feminina enfrentada durante os anos de regime militar, ao mesmo tempo em que também sugere um florescimento da própria sexualidade da mulher.

Entendemos que, ao abordar a temática em questão, o texto de Clarice Lispector, por si só, já está imerso nos signos de resistência, uma vez que a autora utiliza de sua voz literária para dar voz àqueles que, "por muito tempo, foram legados ao silêncio" (SARMENTO-PANTOJA, 2014, p. 18). No entanto, é evidente para nós que a relação "opressor e oprimido", a qual marca diretamente o conceito de resistência, pode ser compreendida no conto sob o viés do masculino que tenta, de todas as formas, subjugar o feminino a uma condição inferior, levando-o dessa forma a uma condição de resistência.

A "vulgarização" de Cidinha faz com que ela acabe sendo entregue, pelo condutor do trem, à polícia na próxima estação, sendo levada para a cadeia e ficando presa por três dias, o que nos sugere, mais uma vez, a repressão contra a figura feminina, já que os agressores, diferentemente da 
protagonista, são ignorados pelas autoridades e seguem a viagem. Ao final do conto, após ser solta, Cidinha descobre, através das manchetes de jornais, que uma moça fora estuprada e assassinada num trem. É quando, por fim, nos confrontamos com o grande ato de espetacularização da violência no conto, a qual acontece através de um meio midiático. Benjamin Moser (2013) ressalta que A língua $d o$ " $P$ " foi o único texto em que Clarice Lispector escreveu uma descrição explícita de estupro, o que comprova novamente o caráter transgressor da obra. A ação nos permite pensar, portanto, em como o conto, após quarenta e cinco anos de sua publicação, mostra-se ainda muito relevante, haja vista que, dia após dia, casos de feminicídio são corriqueiramente noticiados pela imprensa.

Acreditamos ser importante, neste momento, discorrer sobre as duas formas de resistência propostas por Alfredo Bosi, uma vez que estes conceitos nos ajudarão a compreensão os limites entre os signos de resistência no texto de Clarice Lispector. Segundo Bosi, a resistência pode ser classificada como temática e/ou imanente. A resistência temática está estritamente relacionada à questão da cultura e suas distintas formas de manifestação artística, na qual o narrador assume frente às grandes questões latentes de uma época. Em outras palavras, a resistência temática está ligada diretamente ao contexto sociopolítico cultural de um determinado período histórico. Sobre a resistência imanente, por sua vez, Alfredo Bosi afirma que a mesma é independente e não está necessariamente fixada a nenhum fato ou momento histórico em si e que é inerente ao próprio texto narrativo, no qual há uma tensão latente do ser no mundo em relação dialética com outros seres e consigo mesmo.

Sendo assim, o texto A língua do " $P$ " estaria sob a ótica da resistência temática, pois nasce durante o regime ditatorial brasileiro e questiona a postura deste diante da subalternização feminina. É possível analisar o conto, também, a partir da resistência imanente, pois os questionamentos levantados por Clarice não estão presos, necessariamente, a um contexto histórico, pois continuam reverberando nos dias de hoje. No entanto, valemo-nos aqui da proposição de Sarmento-Pantoja ao evidenciar a necessidade de

Ampliar o escopo de classificação das formas de resistência propostas por Bosi, pois consideramos que a resistência temática não é apenas aquela em que a história está inscrita em um tempo histórico definido, ela pode assumir formas bem diferentes, sem que deixe de ser temática, do mesmo modo que a resistência imanente possui elementos que recuperam situações que estão demarcadas historicamente, mas nesse caso, sem um tempo fixo. (SARMENTO-PANTOJA, 2014, p. 28)

As reflexões de Sarmento-Pantoja fazem-se importantes para a compreensão do conceito de resistência no texto de Clarice Lispector, porque este, embora escrito durante os anos de ditadura 
civil-militar, não demarca seu contexto histórico através de citações diretas ao regime, ainda que haja no conto o teor da repressão. É possível inferir, dessa forma, que a resistência temática no conto, para além das fronteiras histórico-políticas, justifica-se por tematizar a violência contra a mulher, bem como por estender essas questões para as futuras gerações e seus futuros leitores, o que confere ao texto um caráter de resistência imanente.

\section{CAIO E SUA TERÇA-FEIRA GORDA}

Nesta seção, analisaremos os aspectos referentes à espetacularização da violência no conto Terça-feira gorda, de Caio Fernando Abreu, publicado em 1982, no livro Morangos Mofados. Dos 18 textos que integram a coletânea, deteremos nossas observações em Terça-feira gorda, no intuito de depreendermos a relação violência-resistência presente na narrativa.

A respeito de Morangos Mofados, consideramos importante destacar a sua organização, uma vez que os contos estão dispostos em três partes: "o mofo", "os morangos" e "morangos mofados". Compreender esta organização é compreender também o teor dos contos que compõem a coletânea, pois cada parte do livro revela-se como uma peça do quebra-cabeça que concebe o retrato do Brasil do início dos anos de 1980. Terça-feira gorda está incluso em "o mofo", seção do livro que sugere, segundo Ana Paula Porto (2002), a putrefação da sociedade, em virtude do "caráter opressor e violento do contexto social" (PORTO, 2002, p. 07). Em vista disso, o conto denuncia, por intermédio de sua temática, uma situação-limite que se revela como sendo reflexo da ditadura civil-militar.

Italo Moriconi (2000) ressalta que, a partir dos anos de 1980, há uma emersão da homossexualidade na contística brasileira. Caio Fernando Abreu foi, por meio de sua obra, um dos autores mais significativos de sua geração a abordar essa temática, muito em virtude do lugar de fala no qual ele estava inserido. Declaradamente homossexual em pleno regime militar, o escritor problematizou o preconceito e a repressão contra esse grupo subalternizado durante a ditadura. Temos aqui, portanto, o primeiro ponto de contato entre o texto de Clarice Lispector e o de Caio Fernando Abreu: ambos podem ser considerados obras de resistência, em razão de notabilizarem indivíduos marginalizados, cujas vozes foram silenciadas pelo estado de exceção pós-64. Nessa perspectiva, o status conferido à obra de Clarice Lispector de "literatura feminina" e a de Caio Fernando de "literatura gay", diferentemente da carga pejorativa, a qual costuma-se associar tais rótulos, carrega em si um teor de resistência, principalmente se levarmos em consideração, como já mencionado anteriormente, o lugar de fala em que estes autores se encontravam. 
Terça-feira gorda trata-se de uma das muitas narrativas na qual encontramos um Caio Fernando Abreu comprometido com a desmistificação de estereótipos a respeito da homossexualidade e ao mesmo tempo sendo o porta-voz de denúncia contra a intolerância, o preconceito e a violência. Narrado em primeira pessoa, o conto é o relato memorialístico de um personagem que vivenciou uma experiência homoerótica, há muitos anos, durante uma festa de carnaval. A escolha de um narrador-personagem revela-se de extrema importância na tessitura do conto, pois abre espaço para uma visão íntima, imersiva e esclarecedora a respeito das relações homossexuais. O que encontraremos, no decorrer da narrativa, é uma explanação das observações e dos desejos mais viscerais do protagonista.

O início do texto é centrado na atração do narrador por outro homem durante uma festa carnavalesca. O jogo de sedução está na forma como o homem desejado samba até ele, olha-o, sorri, o que é correspondido pelo narrador. As descrições fornecidas criam na mente do leitor um forte caráter imagético-erótico que, por vezes, torna-se quase palpável.

Ele encostou o peito suado no meu. Tínhamos pelos, os dois. Os pelos molhados se misturavam. Ele estendeu a mão aberta, passou no meu rosto, falou qualquer coisa. O quê, perguntei. Você é gostoso, ele disse. E não parecia bicha nem nada: apenas um corpo que por acaso era de homem gostando de outro corpo, o meu, que por acaso era de homem também. (ABREU, 2018, p. 344)

$\mathrm{Na}$ passagem, Caio Fernando Abreu rompe com a visão estereotipada da figura do homossexual, associada quase sempre a trejeitos, comportamentos considerados afeminados e ao ato de estar travestido. O que encontramos aqui, no entanto, como bem destaca o próprio narrador, são homens em sua forma mais crua: cheios de pelos, suor, masculinidade e um desejo ardente por contato físico. Consideramos, dessa forma, que a iconoclastia quanto à representação do homossexual no conto é um dos muitos fatores que confere à narrativa um importante caráter de resistência.

A partir desse momento, quando os dois já estão próximos o suficiente para trocar carícias e afagos, nos deparamos com o primeiro ato de violência no conto. Trata-se de um comportamento intimidante vindo dos que estão ao redor, refletido em palavras e no tom de voz com que elas são proferidas, nos olhares e até mesmo nos empurrões. É interessante notarmos, neste momento, a pluralidade da imagem criada por Caio Fernando Abreu: os personagens estão em uma festa de carnaval, período no qual pressupõe-se o "tudo é permitido", inclusive o "soltar as frangas". Sendo assim, a escolha de ambientação para o conto durante uma festa carnavalesca sugere-nos uma perspectiva de liberdade sexual, o que acreditamos ser outro ponto em comum com o texto de Clarice Lispector, o qual, ao expor a "vulgarização" de Cidinha, traz à tona a autodescoberta do corpo 
feminino. No entanto, o texto de Caio Fernando, diferentemente do de Clarice Lispector, não se centra na autodescoberta do corpo. Os personagens, ao que tudo indica, entendem seus desejos homoeróticos. O enfoque está, portanto, em consumar o desejo pré-estabelecido. Todavia, apesar de toda a liberdade que o período carnavalesco pressupõe, a situação revela-se absurdamente irônica, uma vez que o preconceito e repressão fazem-se presentes no próprio ambiente festivo.

Ai-ai, alguém falou em falsete, olha as loucas, e foi embora. Em volta, olhavam. [...] Nos empurravam em volta, tentei protegê-lo com meu corpo, mas ai-ai repetiam empurrando, olha as loucas, vamos embora daqui, ele disse. E fomos saindo colados pelo meio do salão, a purpurina da cara dele cintilando no meio dos gritos. Veados, a gente ainda ouviu, recebendo na cara o vento frio do mar. (ABREU, 2018, p. 345)

Logo após saírem do local da festa, os homens se dirigem a uma praia, na qual acontecerá, de fato, a consumação do ato sexual entre eles. Por meio de uma linguagem simples e direta, mas não menos profunda, metafórica e alusiva, Caio Fernando Abreu constrói a cena mais bela do texto, o ápice do desejo entre os protagonistas.

Tiramos as roupas um do outro, depois rolamos na areia. [...] A gente se apertou um contra o outro. A gente queria ficar apertado assim porque nos completávamos desse jeito, o corpo de um sendo a metade perdida do corpo do outro. Tão simples, tão clássico. A gente se afastou um pouco, só para ver melhor como eram bonitos nossos corpos nus de homens estendidos um ao lado do outro, iluminados pela fosforescência das ondas do mar. Plâncton, ele disse, é um bicho que brilha quando faz amor. E brilhamos. (ABREU, 2018, p. 346)

$\mathrm{Na}$ passagem, Caio Fernando viabiliza não apenas a descrição do ato sexual entre os protagonistas, mas também o que podemos conceber como uma poética de resistência. Isso porque a cena é apresentada, segundo Flávio Camargo (2010), a partir de "uma densidade poética presente no ritmo das frases, na sonoridade e na intensidade das metáforas" (CAMARGO, 2010, p. 07). A alegoria do plâncton, por exemplo, o bicho que brilha quando faz amor, não apenas sugeri-nos a consumação do sexo entre os personagens, os quais, naquele momento, tornam-se um só, como também alude ao próprio Carnaval, período festivo em que a narrativa acontece. Lembremos, além disso, que a cena descrita se passa ao ar livre, em plena praia, sob a luz das estrelas, o que nos abre interpretações no tocante à total exposição da sexualidade desses personagens frente ao mundo, mesmo que diante de situações adversas.

A decisão de Caio Fernando em narrar a cena da maneira mais poética possível confere-nos uma imersão ainda mais acentuada no que está sendo dito. Embora haja uma erotização do corpo masculino, a imagética da relação homossexual em nenhum momento beira o pornográfico e agride 
o leitor, justamente por conta de seu caráter poético. Sendo assim, ao revelar-nos a intimidade e o prazer entre os dois homens, o autor faz de Terça-feira gorda um dos raros casos da literatura brasileira em que o sexo gay é apresentado, característica que também entendemos como resistente.

Consideramos esse mais um dos inúmeros pontos de contato entre o texto de Clarice Lispector e Caio Fernando Abreu. Isso porque as representações literárias quanto à sexualidade feminina, vistas sob a ótica de uma escritora, são quase que escassas em nossa literatura. Em A língua do " $P$ ”, assim como em Terça-feira gorda, os autores resistem à coerção de grupos que perderam os direitos de seus próprios corpos.

E então, durante o encontro sexual, os protagonistas são surpreendidos pelas mesmas pessoas que os haviam constrangido durante a festa. Neste momento, temos o segundo ato de violência descrito no conto, desta vez não mais associado a comportamentos intimidantes, e sim à agressão física.

Mas vieram vindo, então, e eram muitos. Foge, gritei, estendendo o braço. Minha mão agarrou um espaço vazio. O pontapé nas costas fez com que me levantasse. Ele ficou no chão. Estavam todos em volta. Ai-ai, gritavam, olha as loucas. Olhando para baixo, vi os olhos dele muito abertos e sem nenhuma culpa entre as outras caras dos homens. A boca molhada afundando no meio duma massa escura, o brilho de um dente caído na areia. Quis tomá-lo pela mão, protegê-lo com meu corpo, mas sem querer estava sozinho e nu correndo pela areia molhada, os outros todos em volta, muito próximos. (ABREU, 2018, p. 346)

Ao final do conto, o narrador consegue escapar dos agressores. Porém, o homem que fora seu companheiro acaba sendo violentamente assassinado, como sugere o trecho:

Fechando os olhos então, como um filme contra as pálpebras, eu conseguia ver três imagens se sobrepondo. Primeiro o corpo suado dele, sambando, vindo em minha direção. Depois as Plêiades, feito uma raquete de tênis suspensa no céu lá em cima. E finalmente a queda lenta de um figo muito maduro, até esborrachar-se contra o chão em mil pedaços sangrentos. (ABREU, 2005, p. 59)

Neste momento, destaca-se a espetacularização da violência. Diferentemente de A língua do “ $P$ ”, no qual a violência é espetacularizada por meio de um recurso midiático e pela repercussão que a notícia do estupro e assassinato implica sobre Cidinha, o que temos em Terça-feira gorda é uma violência exposta de maneira crua e ao mesmo tempo carregada de um forte teor poético. Vê-se o corpo sendo violentado, vê-se o sangue escorrendo desse corpo e, ainda assim, a imagética da lenta queda do figo maduro mescla-se com a cena brutal, preenchendo-a de sugestão.

Consideramos relevante discorrer sobre a função do narrador para o texto. Como referenciado nos parágrafos anteriores, Caio Fernando adere a uma narrativa em primeira pessoa, no intuito de 
conduzir o leitor aos sentimentos mais íntimos do protagonista, criando uma experiência literária de plena imersão. Porém, essa escolha ganha proporções ainda maiores se levarmos em conta o teor testemunhal da narrativa, a qual, ainda que ficcionada, propõe-se em fazer um retrato de uma realidade social. Nessa perspectiva, Sarmento-Pantoja (2013) reflete sobre o chamado narrador superste, descrevendo-o como aquele que "traz consigo uma importuna marca daqueles que não sucumbiram completamente, já que permanecem vivos e conseguem narrar" (SARMENTOPANTOJA, 2013, p. 97). Desse modo, entendemos a importância, ao final de Terça-feira gorda, do escape do protagonista contra os atos de violência, uma vez que ele deixará de ser um mero narrador e se tornará testemunha, ou seja, o sobrevivente da situação-limite, o qual será responsável por (re)conceber uma imagem a partir de sua memória.

Apreendendo a condição deste narrador, que sobrevive e tenta reelaborar o seu passado, a espetacularização da violência presente no ato final da narrativa reverbera de forma muito mais contundente, principalmente se levarmos em consideração que

o espetáculo não está ali para divertir ou horrorizar simplesmente, ele representa a performance de um narrador que precisa que o leitor passe a olhá-lo como uma imagem que busca desvelar o encoberto. Para que desse modo o testemunho desse narrador superste possa contribuir para uma leitura mais ampla e completa das imagens que assombram este narrador. Ao mesmo tempo possibilita compreender os porquês desse encobrimento. (SARMENTO-PANTOJA, 2013, p. 97)

Portanto, ao encerrar o texto com a cena do homicídio, envolta de um forte caráter poético, Caio Fernando não apenas espetaculariza a violência como também abre um continuum entre ficção e realidade, o que acaba por conduzir o leitor a um questionamento quanto à condição social de homens que, ao "romper com os padrões tradicionais, são severamente perseguidos e punidos por aqueles que defendem a ordem, a moral e os 'bons costumes"' (PORTO, 2002, p. 07). A imagem proporcionada pelo conto nos instiga, então, a desvelar aquilo que está encoberto e buscar a compreensão desse encobrimento.

Assim como em $A$ língua do " $P$ ”, embora saibamos que estas obras foram produzidas entre os anos de 1964 e 1985, a ditadura civil-militar não aparece explicitamente em Terça-feira gorda, ainda que ela esteja lá. Nesse sentido, Cecília Rezende e Cláudia Tartáglia salientam a

conexão entre o contexto social em que o conto foi produzido e a postura dos personagens. Os agressores no conto adotam uma posição ideológica favorável às ideias autoritárias e preconceituosas difundidas no período de publicação do livro Morangos Mofados, em 1982. Este período embora de transição da ditadura para um 
regime democrático deixa marcas que são reproduzidas nas relações sociais entre os indivíduos. (REZENDE \& TARTÁGLIA, 2010, p. 32)

As reflexões das autoras nos remetem novamente às formas de resistência propostas por Alfredo Bosi e dialogadas com os estudos de Sarmento-Pantoja. Nesse ínterim, podemos depreender que o texto de Caio Fernando Abreu, assim como o de Clarice Lispector, está imerso dentro da chamada resistência temática: primeiro, porque o autor opõe-se contra o teor de repressão advindo do regime ditatorial pós-64; e segundo, por tematizar, por meio do texto literário, a violência contra homossexuais. Atrelado a isso, o texto também se configura dentro da chamada resistência imanente, visto que as questões discutidas por Caio Fernando Abreu, bem como as de Clarice Lispector, são relevantes não apenas por estarem ligadas a um contexto histórico específico, mas também pelo rompimento dessas fronteiras históricas, alcançando longevidade e significância independentemente de quando e onde as vozes ali contidas possam ser ouvidas.

\section{CONSIDERAÇÕES FINAIS}

Diante dos comentários apresentados nesta pesquisa, a respeito da espetacularização da violência na contística de Clarice Lispector e Caio Fernando Abreu, ratificamos a importância do texto literário quanto a sua instrumentalização dentro dos signos de resistência. Em uma época marcada pelo cerceamento dos direitos básicos, pela censura nos grandes meios midiáticos e por uma melancolia enraizada no esvaziamento do indivíduo enquanto ser, o gênero conto, com suas peculiares narrativas, foi (e continua sendo) um dos principais mecanismos de questionamento e denúncia contra o autoritarismo.

Nessa perspectiva, Clarice Lispector e Caio Fernando Abreu configuram-se como porta-vozes de uma geração que, indo pela contramão, concatenou e refletiu, através do texto literário, o teor de insegurança presente durante o regime ditatorial pós-64. As cenas de violência, analisadas nos textos, expõem ao leitor as mais desonrosas situações humanas enfrentadas por grupos marginalizados em plena ditadura civil-militar. Porém, muito mais do que um retrato histórico, estas narrativas ganham força dado o seu valor de atualidade e urgência, servindo como um grito de alerta para o nosso tempo, no qual o fascismo revela-se cada mais presente no mundo contemporânea.

Em nossa pesquisa, detemos os estudos referentes à espetacularização da violência em apenas dois contos. No entanto, considerando a vasta obra dos autores argumentados, entendemos que os debates não se dão por encerrados aqui. Esperamos, dessa forma, que este trabalho seja o incentivo a 
futuros pesquisadores, os quais desejarem, assim como nós, desbravar a escrita destes importantes nomes da literatura brasileira. Sejamos corajosos à semelhança de Clarice e Caio!

\section{REFERÊNCIAS}

ABREU, Caio Fernando. Carta a Hilda Hilst. In: Caio 3D, o essencial da década de 1970. Rio de Janeiro: Agir, 2005.

ABREU, Caio Fernando. Carta ao Zézim. In: Morangos Mofados. Rio de Janeiro: Agir, 2005.

ABREU, Caio Fernando. Contos completos. São Paulo: Companhia das Letras, 2018.

AGAMBEN, Giorgio. O que é o contemporâneo? e outros ensaios. Chapecó: Argos, 2009.

ASSIS, Machado de. Contos escolhidos. São Paulo: Martin Claret, 2001.

BOSI, Alfredo. História concisa da literatura brasileira. São Paulo: Cultrix, 2006.

BOSI, Alfredo. Literatura e resistência. São Paulo: Companhia das Letras, 2002.

BRANDILEONE, Ana Paula F. Nobile. Violência e resistência em "Terça-feira gorda", de Caio Fernando Abreu. Caderno Seminal Digital, ano 20, nº 21, v. 21, p. 216-232, jan-jun/2014.

CAMARGO, Flávio Pereira. Homoerotismo e Violência em "Terça-Feira Gorda”, Conto de Caio Fernando Abreu. In: Fazendo Gênero. Santa Catarina: UFSC, 2010.

COSTA, Amanda Lacerda. 360 graus: o inventário astrológico de Caio Fernando Abreu. Universidade Federal do Rio Grande do Sul. Porto Alegre, 2008.

DALCASTAGNÈ, Regina. Renovação e permanência: o conto brasileiro da última década. Estudos de Literatura Contemporânea, $n^{\circ}$ 11. Brasília, janeiro/fevereiro de 2001, p. 03-17.

GOMES, Carlos Magno. Marcas da violência contra a mulher na literatura. Revista Diadorim/ Revista de Estudos Linguísticos e Literários do Programa de Pós-Graduação em Letras Vernáculas da Universidade Federal do Rio de Janeiro. Volume 13, p. 01-11, Julho 2013.

HOLANDA, Heloisa de. Hoje não é dia de rock. In: Contos completos. São Paulo: Companhia das Letras, 2018.

LISPECTOR, Clarice. Todos os contos. Organização de Benjamin Moser. Rio de Janeiro: Rocco, 2016.

LOBATO, Monteiro. Contos completos. São Paulo: Biblioteca Azul, 2014. 
MASSOTTI, João Paulo. Repressão, censura e silenciamentos: a ditadura militar brasileira aos olhos de Caio Fernando Abreu. Frederico Westphalen: Universidade Regional Integrada do Alto Uruguai e das Missões, 2016.

MORICONI, Ítalo (organizador). Os cem melhores contos brasileiros do século. Rio de Janeiro: Objetiva, 2000.

MOSER, Benjamin. Clarice. São Paulo: Cosac Naify, 2013.

PAVIS, Patrice. Dicionário de teatro. Rio de Janeiro: Perspectiva, 1999.

PELLEGRINI, Tânia. No fio da navalha: literatura e violência no Brasil de hoje. In: DALCASTAGNÈ, Regina. Ver e imaginar o outro: alteridade, desigualdade, violência na literatura brasileira contemporânea. Vinhedo: Horizonte, 2008. p. 41-56.

PEREIRA, Arthur Oriel. O que é lugar de fala?. Leitura: Teoria \& Prática, Campinas, São Paulo, v.36, n.72, p.153-156, 2018.

PESAVENTO, Sandra. Memória e história: as marcas da violência. Fênix - Revista de História e Estudos Culturais. Vol. 3. Ano III. no 3. p. 01-15. Julho/ Agosto/ Setembro de 2006.

PORTO, Ana Paula Teixeira. Preconceito, Repressão Sexual e Violência em Caio Fernando Abreu. In: Ao pé da Letra. Recife: UFPE, 2002, n.4.1, p.1-8.

REZENDE, Cecília \& TARTÁGLIA, Cláudia. O homoerotismo em Caio Fernando Abreu: um cenário de preconceito e violência em "Terça-Feira Gorda". Revista FACEVV. Vila Velha. Número 5. Jul./Dez. 2010. p. 31-39.

SARMENTO-PANTOJA, Augusto. Literatura e arte de resistência. In: Estudos de Literatura e Resistência. Campinas, SP: Pontes Editores, p. 11-31, 2014.

SARMENTO-PANTOJA, Augusto. Sobre o espetáculo em Guy Debord. In: Literatura e Cinema de Resistência: novos olhares sobre a memória. Rio de Janeiro: Editora Oficina Raquel, p. 95-104, 2013.

SCHØLLHAMMER, Karl Erik. Fiç̧ão brasileira contemporânea. Rio de Janeiro: Civilização Brasileira, 2009. 